\title{
Similarity of Ribosomal Proteins Studied by Two-Dimensional Coelectrophoresis for Identification of Gram-Positive Bacteria
}

\author{
KEIKO OCHIAI, ${ }^{*}$ KAZUHISA UCHIDA, AND ISAO KAWAMOTO \\ Kyowa Hakko Kogyo Co., Ltd., Tokyo Research Laboratories, 3-6-6 Asahimachi, Machidashi, Tokyo, Japan
}

\begin{abstract}
A two-dimensional electrophoresis method was devised for comparing ribosomal proteins from different bacteria. First-dimension separation of the proteins was carried out by nonequilibrium pH gradient gel electrophoresis in glass capillary tubes. Next, the first-dimension gels were developed in a slab gel by sodium dodecyl sulfate-polyacrylamide gel electrophoresis. Within about $3 \mathrm{~h}$ (total running time), 40 to 48 distinct and compact ribosomal protein spots were detected in each of the 34 strains belonging to eight genera of gram-positive bacteria which we studied. Similarity coefficients $\left(S_{\mathrm{AB}}\right.$ values) among the proteins of Corynebacterium and Arthrobacter strains were calculated by determining the numbers of coincident spots obtained by coelectrophoresis. The $S_{\mathrm{AB}}$ values between strains having DNA relatedness values of more than $61 \%$ (strains of the same species) were greater than 0.85 , whereas the $S_{\mathrm{AB}}$ values between strains of different species were less than 0.45. Ribosomal protein analysis by our improved method is a potential tool for species identification of bacteria.
\end{abstract}

Ribosomes are made up of three separate RNA molecules and more than 50 species of ribosomal proteins. The structural regions essential for function have been conserved during evolution. Therefore, ribosomal constituents have attracted considerable attention in phylogenetic investigations of organisms.

Ribosomal proteins have been analyzed by different methods, including one- and two-dimensional electrophoresis, immunochemical cross-reactions, and amino acid sequencing. Two-dimensional gel electrophoresis has greatly facilitated the resolution of ribosomal proteins and has made it possible to compare the proteins of different organisms. For separation on gels, various systems have been devised for the first and second dimensions. This method has been applied to the taxonomy of species of the family Enterobacteriaceae (4) and of the genus Bacillus (3) and has been extended to other groups of organisms. Several species of the family Enterobacteriaceae and of the genus Bacillus were shown to be very similar in their ribosomal protein patterns within the family and within the genus. On the other hand, some Streptomyces species were shown to exhibit striking variability in their ribosomal protein patterns (12). Also, certain ribosomal proteins (the AT-L30 proteins) were found by Ochi (13) and Ochi et al. (14) to exhibit electrophoretic mobilities that were specific for each genus of actinomycetes.

Whether analysis of ribosomal protein patterns is useful for species identification of eubacteria is still uncertain, because the currently available information is limited to ribosomal proteins of a few bacterial species and also is not based on exact comparisons of individual protein spots. In addition, to obtain similarity coefficients for the proteins from many strains, it would be desirable to develop the previously described methods, especially with respect to spot size resolved, sensitivity, and running time.

In this report, we describe an improved two-dimensional coelectrophoretic analysis method for obtaining the similarity coefficients of total ribosomal proteins. We also discuss

\footnotetext{
${ }^{*}$ Corresponding author.
}

the relationship between ribosomal protein similarity and DNA-DNA complementarity.

\section{MATERIALS AND METHODS}

Bacterial strains. The bacterial strains used in this study are listed in Table 1.

Preparation of ribosomes. Lactobacillus delbrueckii was grown in a lactobacillus culture medium (Nissui) at $37^{\circ} \mathrm{C}$, and Escherichia coli was grown in a brain heart infusion medium (Difco) at $37^{\circ} \mathrm{C}$. The other strains used in this study were grown in nutrient broth medium (Kyokuto), which contained $0.5 \%$ yeast extract, at $28^{\circ} \mathrm{C}$. After cultivation for 4 to $6 \mathrm{~h}$ (mid-exponential phase), cells from each $500-\mathrm{ml}$ culture were collected by centrifugation, washed in TSM buffer $(10 \mathrm{mM}$ Tris- $\mathrm{HCl}, 3 \mathrm{mM}$ succinic acid, $10 \mathrm{mM}$ magnesium chloride; $\mathrm{pH} 8.0$ ), and resedimented. Then they were resuspended in TSM buffer containing $10 \mu \mathrm{g}$ of DNase per ml. The cells were disrupted in a Braun model MSK cell homogenizer with glass beads (diameter, 0.1 to $0.11 \mathrm{~mm}$ ) for $3 \mathrm{~min}$. The cell debris was removed by centrifugation at $25,000 \times g$ for $30 \mathrm{~min}$. The ribosomes in the supernatant were purified by using the method of Kurland (9), and the purified ribosomes were used as the $70 \mathrm{~S}$ ribosome preparation for subsequent experiments.

Preparation of total ribosomal proteins. Ribosomal proteins were prepared as described below by the method of Hardy et al. (6). The ribosomal preparation described above was dissolved in TSM buffer, and then 2 volumes of glacial acetic acid and 0.1 volume of $1 \mathrm{M}$ magnesium chloride (based on the original volume) were added simultaneously. The extraction mixture was stirred vigorously for $45 \mathrm{~min}$ in an ice bath. The precipitate, which contained rRNA, was removed by centrifugation at $12,000 \times g$ for $10 \mathrm{~min}$. For further extraction of the ribosomal proteins, the precipitated RNA was dissolved in $3 \mathrm{ml}$ of $67 \%$ (vol/vol) acetic acid containing $33 \mathrm{mM}$ magnesium chloride, and the preparation was stirred for $20 \mathrm{~min}$ in an ice bath. After centrifugation at $12,000 \times g$ for $10 \mathrm{~min}$, the supernatant was collected, combined, and dialyzed overnight against $2 \%$ (vol/vol) glacial acetic acid. The dialysate was frozen, lyophilized, and stored at $-80^{\circ} \mathrm{C}$. 
TABLE 1. Strains used in this study

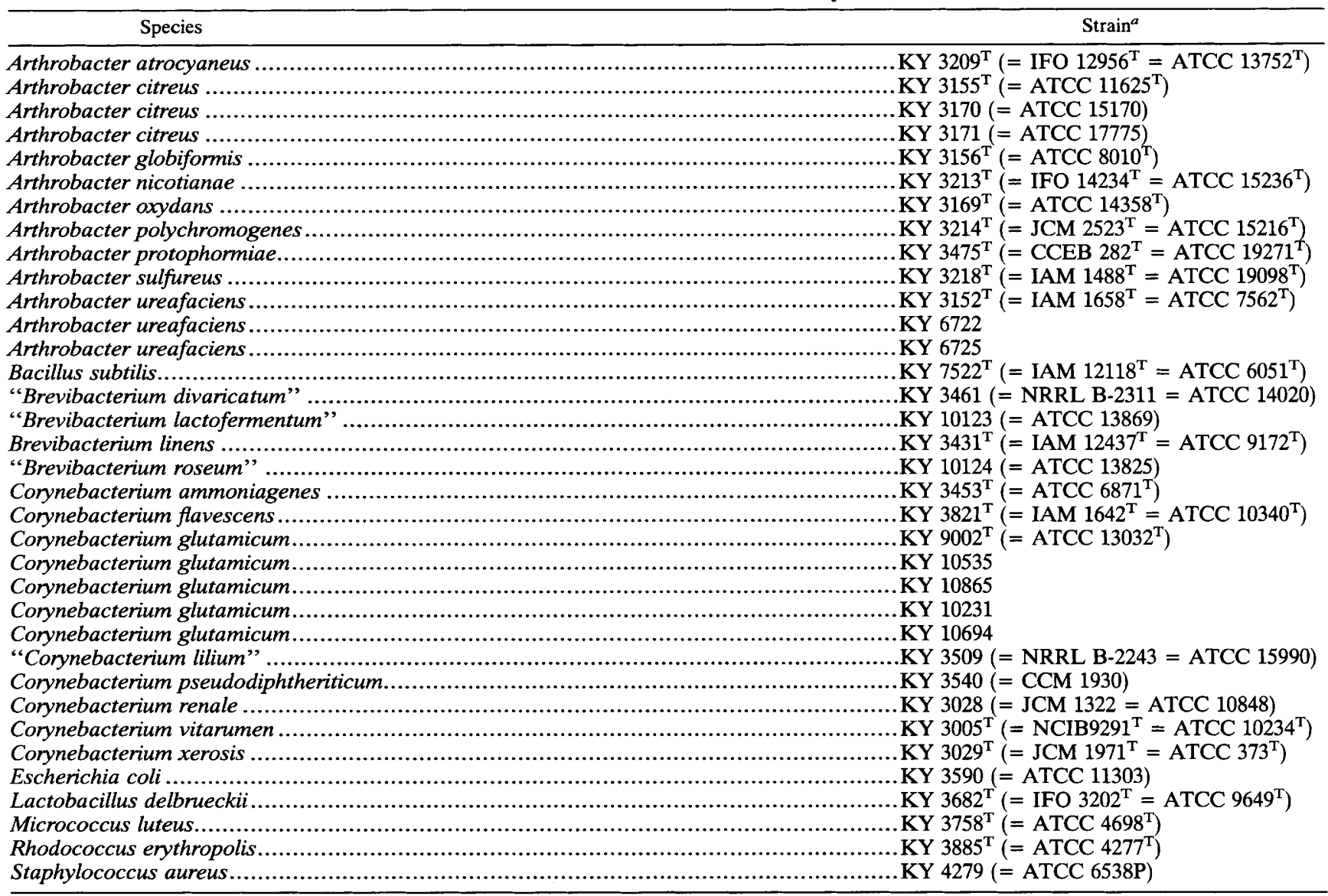

a Abbreviations: KY, Tokyo Research Laboratories, Kyowa Hakko Co., Ltd., Machida, Japan; ATCC, American Type Culture Collection, Rockville, Md.; CCEB, Culture Collection of Entomogenous Bacteria, Institute of Entomology, Prague, Czechoslovakia; CCM, Czechoslovak Collection of Microorganisms, J. E. Purkyne University, Brno, Czechoslovakia; IAM, Institute of Applied Microbiology, University of Tokyo, Tokyo, Japan; IFO, Institute for Fermentation, Osaka, Japan; JCM, Japan Collection of Microorganisms, Wako, Japan; NCIB, National Collection of Industrial Bacteria, NCIMB Ltd., Aberdeen, Scotland; NRRL, Agricultural Research Service Culture Collection, Northern Regional Research Center, Peoria, Ill.

Electrophoresis in the first dimension. The nonequilibrium $\mathrm{pH}$ gradient gel electrophoretic method described by O'Farrell et al. (15) was modified as described below. The separation gel mixture contained (per $4 \mathrm{ml}$ ) $1.96 \mathrm{~g}$ of urea, $20 \mu \mathrm{l}$ of Nonidet P-40, $100 \mu \mathrm{l}$ of ampholine ( $\mathrm{pH} 3.0$ to 10.0 ), $0.16 \mathrm{~g}$ of acrylamide, $4 \mathrm{mg}$ of $N, N^{\prime}$-methylene-bisacrylamide, $9 \mu \mathrm{l}$ of $N, N, N^{\prime}, N^{\prime}$-tetramethylethylenediamine, and $20 \mu \mathrm{l}$ of $10 \%$ (wt/vol) ammonium persulfate. For first-dimension electrophoresis, three glass capillary tubes (length, $42 \mathrm{~mm}$; inner diameter, $1.3 \mathrm{~mm}$ ) were used. The prepared gels could be kept refrigerated for several months with no adverse effects in tightly sealed tubes by wrapping them with a polyethylene sheet. Ribosomal protein samples were dissolved at concentrations of 100 to $200 \mu \mathrm{g} / 10 \mu \mathrm{l}$ in sample buffer containing (per $100 \mathrm{ml}$ ) $36 \mathrm{~g}$ of urea, $1 \mathrm{ml}$ of Nonidet $\mathrm{P}-40$, and $5 \mathrm{ml}$ of 2 -mercaptoethanol. Usually, 2 to $4 \mu \mathrm{l}$ of a sample was applied. The upper and lower electrode solutions were 0.01 $\mathrm{M} \mathrm{H}_{3} \mathrm{PO}_{4}$ and $0.04 \mathrm{M} \mathrm{NaOH}$, respectively. Electrophoresis was carried out at 0.1 to $0.15 \mathrm{~mA}$ per gel at room temperature for 15 to $20 \mathrm{~min}$ with a model 3500 computerized programmable power supply (TEFCO).

Electrophoresis in the second dimension. After the first run, the gels were removed from the glass capillary tubes by careful extrusion with injection and were dialyzed immedi- ately for $5 \mathrm{~min}$ against $1 \mathrm{ml}$ of dialyzing buffer containing (per $100 \mathrm{ml}$ ) $25 \mathrm{mM}$ Tris- $\mathrm{HCl}, 2 \mathrm{~g}$ of sodium dodecyl sulfate, $5 \mathrm{ml}$ of 2-mercaptoethanol, and $10 \mathrm{ml}$ of glycerol. Three dialyzed gels (length, $42 \mathrm{~mm}$ ) were applied side by side to a seconddimension slab gel which was $138 \mathrm{~mm}$ wide, $125 \mathrm{~mm}$ long, and $1 \mathrm{~mm}$ thick. Second-dimension electrophoresis was performed with a $14 \%$ sodium dodecyl sulfate-polyacrylamide gel at $30 \mathrm{~mA}$ per gel until the tracking dye reached the bottom (about $130 \mathrm{~min}$ ). The gels were stained with $0.5 \%$ Coomassie brilliant blue R-250 in $45 \%$ methanol-10\% acetic acid-water for $2 \mathrm{~h}$ at room temperature and destained with $40 \%$ methanol-10\% acetic acid-water for several hours.

\section{RESULTS}

Resolution of two-dimensional gel electrophoresis. The electrode conditions of the nonequilibrium $\mathrm{pH}$ gradient gel electrophoresis used in the first dimension with glass capillary tubes were examined with respect to the current and running time. When first-dimension electrophoresis was performed at 0.1 to $0.15 \mathrm{~mA}$ per gel for 17 to $22 \mathrm{~min}$, the total ribosomal proteins from $E$. coli KY 3590 (= ATCC 11303) were separated into 46 compact spots on the two-dimensional electrophoresis gel, although several proteins mi- 


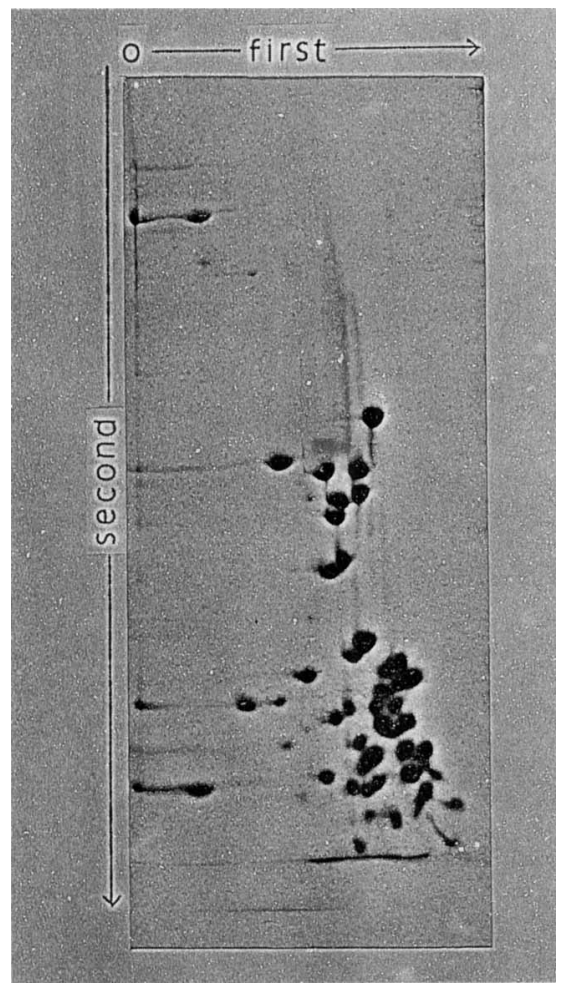

FIG. 1. Two-dimensional electrophoresis of total ribosomal proteins from $E$. coli. The first dimension was run at $0.15 \mathrm{~mA}$ per gel for $17 \mathrm{~min}$. The second-dimension electrophoretic conditions are described in Materials and Methods. The ribosomal proteins migrated from the left side to the right (cathode) side. $\mathrm{O}$, origin in the first dimension.

grated to the same positions (Fig. 1). With a running time of less than $10 \mathrm{~min}$ and a current of $0.1 \mathrm{~mA}$ per gel, the proteins failed to migrate, whereas with electrophoresis for more than $40 \mathrm{~min}$ at a current of $0.1 \mathrm{~mA}$ per gel or for more than $20 \mathrm{~min}$ at a current of $0.4 \mathrm{~mA}$ per gel many proteins migrated so far to the right side that the number of spots detected decreased markedly (data not shown).

Reproducibility of two-dimensional gel electrophoresis. $\mathrm{Re}$ producible separation of the ribosomal proteins from Corynebacterium glutamicum KY $9002^{\mathrm{T}}$ (= ATCC $13032^{\mathrm{T}}$ ) was confirmed under several conditions. First-dimension electrophoresis was performed with a current of $0.1 \mathrm{~mA}$ per gel for $22 \mathrm{~min}$. The total ribosomal proteins were separated into 43 compact, clear spots and 6 small, pale spots (Fig. 2A). When several first-dimension gels were prepared at the same time, the protein patterns were not affected, even if some gels were stored at $5^{\circ} \mathrm{C}$ for several months. Furthermore, the level of reproducibility was very high when second-dimension electrophoresis was performed after the first-run gels were stored at $-20^{\circ} \mathrm{C}$ for 1 week (Fig. 2B). However, the migration patterns of a few basic ribosomal proteins, which had molecular weights less than about 11,000 and $\mathrm{pI}$ values greater than 12 , were not constant under all conditions.

Application to analysis of ribosomal proteins from grampositive bacteria. Our method was applied to an analysis of the ribosomal proteins from species belonging to eight genera of gram-positive bacteria. Figure 3 shows the patterns obtained for Arthrobacter globiformis KY $3156^{\mathrm{T}}$ (= ATCC

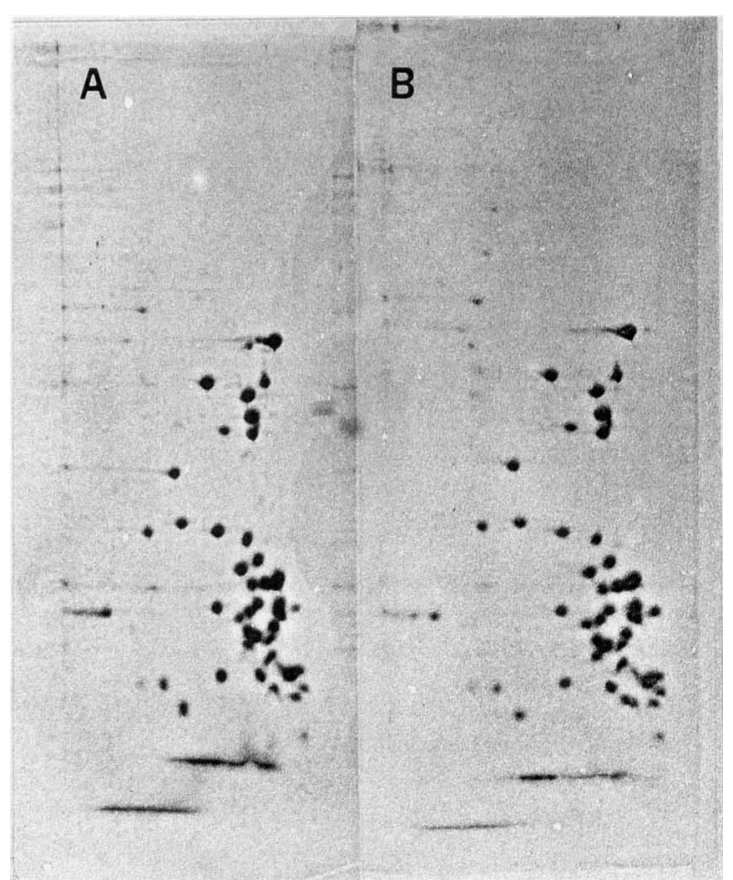

FIG. 2. Reproducibility of separation of ribosomal proteins. Ribosomal proteins from $C$. glutamicum $\mathrm{KY} 9002^{\mathrm{T}}$ were used. The first-dimension gels were prepared at the same time. (A) Firstdimension electrophoresis was performed at $0.1 \mathrm{~mA}$ per gel for 22 min. (B) Gel electrophoresed at a different time under the same conditions as those used for the gel in panel A, after the firstdimension electrophoretic gel was stored at $-20^{\circ} \mathrm{C}$ for 1 week.

$8010^{\mathrm{T}}$ ), Bacillus subtilis KY $7522^{\mathrm{T}}$ (= IAM $\left.12118^{\mathrm{T}}\right)$, Brevibacterium linens $\mathrm{KY} 3431^{\mathrm{T}}$ (= IAM $12437^{\mathrm{T}}$ ), C. glutamicum KY $9002^{\mathrm{T}}\left(=\right.$ ATCC $\left.13032^{\mathrm{T}}\right)$, L. delbrueckii KY $3682^{\mathrm{T}}(=$ IFO $3202^{\mathrm{T}}$ ), Micrococcus luteus KY $3758^{\mathrm{T}}\left(=\right.$ ATCC $4698^{\mathrm{T}}$ ), Rhodococcus erythropolis KY $3885^{\mathrm{T}}\left(=\mathrm{ATCC} 4277^{\mathrm{T}}\right.$ ), and Staphylococcus aureus KY 4279 (= ATCC 6538P). Distinct spots, ranging in number from 43 to 46 , were detected. About six to nine proteins migrated into the regions corresponding to molecular weights of 25,000 to 33,000 , while most of the rest of the proteins appeared in the regions corresponding to molecular weights of less than 18,000 .

Similarity coefficients of ribosomal proteins. Two individual ribosomal protein preparation electrophoretograms and a coelectrophoretogram of a mixture of two ribosomal protein preparations run on the same slab gel were compared. For example, in the comparison of $C$. glutamicum KY $9002^{\mathrm{T}}$ and "Brevibacterium lactofermentum" KY 10123 (= ATCC 13869), 44 of 46 proteins from each strain migrated to the same positions, whereas 2 proteins from $C$. glutamicum $\mathrm{KY}$ $9002^{\mathrm{T}}$ and 3 proteins from "Brevibacterium lactofermentum" KY 10123 migrated to different positions (Fig. 4B, arrows). As shown in Fig. 4E, more than 70 proteins were detected by coelectrophoresis of ribosomal proteins from $A$. globiformis KY $3156^{\mathrm{T}}$ and $E$. coli $\mathrm{KY} 3590$. About 30 proteins from $A$. globiformis KY $3156^{\mathrm{T}}$ did not share spots with the proteins from $E$. coli KY 3590 . Thus, similarity coefficients for the ribosomal proteins from two strains were obtained easily by our method. Similarity $\left(S_{\mathrm{AB}}\right)$ values were determined as follows: 2(number of coincident spots)/total number of spots for both proteins. The $S_{\mathrm{AB}}$ value for the ribosomal proteins of C. glutamicum KY $9002^{\mathrm{T}}$ and "Brevibacterium lactofermentum" KY 10123 was 0.96 , and the 


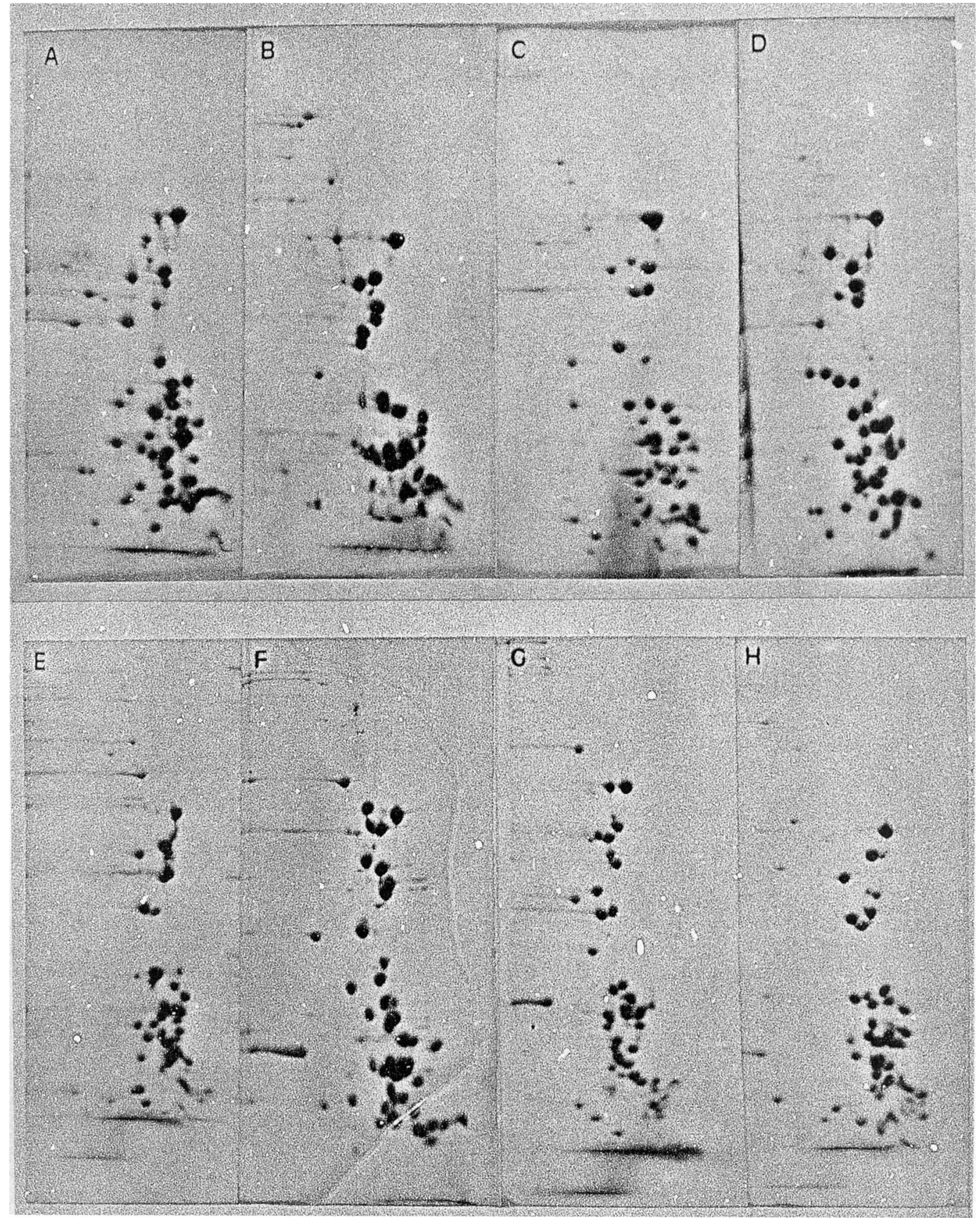

FIG. 3. Two-dimensional electrophoresis of total ribosomal proteins from gram-positive bacteria. (A) A. globiformis KY $3156^{\mathrm{T}}$. (B) Bacillus subtilis $\mathrm{KY} 7522^{\mathrm{T}}$. (C) Brevibacterium linens $\mathrm{KY} 3431^{\mathrm{T}}$. (D) C. glutamicum $\mathrm{KY} 9002^{\mathrm{T}}$. (E) L. delbrueckii $\mathrm{KY} 3682^{\mathrm{T}}$. (F) M. luteus KY $3758^{\mathrm{T}}$. (G) R. erythropolis KY $3885^{\mathrm{T}}$. (H) S. aureus KY 4279.

$S_{\mathrm{AB}}$ value for the ribosomal proteins of $E$. coli $\mathrm{KY} 3590$ and A. globiformis KY $3156^{\mathrm{T}}$ was 0.26 .

Influence of mutations on conservation of ribosomal proteins. The ribosomal proteins of amino acid-producing mutants, which were auxotrophic and/or antimetabolite-resistant strains of $C$. glutamicum and Arthrobacter ureafaciens, were compared with the ribosomal proteins of the respective wild-type strains. For example, as shown in Fig. 5, most of the spots for the ribosomal proteins from strain KY 10231, which was a lysine-producing mutant of $C$. glutamicum KY $9002^{\mathrm{T}}$, migrated to the same positions as the spots for strain
KY $9002^{\mathrm{T}}$ proteins when coelectrophoresis was performed. As shown in Table 2, the $S_{\mathrm{AB}}$ values of six mutants ranged from 0.95 to 0.99 . Thus, alterations in ribosomal proteins by sequential mutations were not obvious on two-dimensional electrophoresis gels.

Correlation between ribosomal protein similarity and DNADNA relatedness. Whether ribosomal protein similarity was useful for identification of bacterial species was investigated. It has been proposed that the phylogenetic definition of a species should be as follows: a species comprises strains that exhibit approximately $70 \%$ or greater DNA-DNA related- 


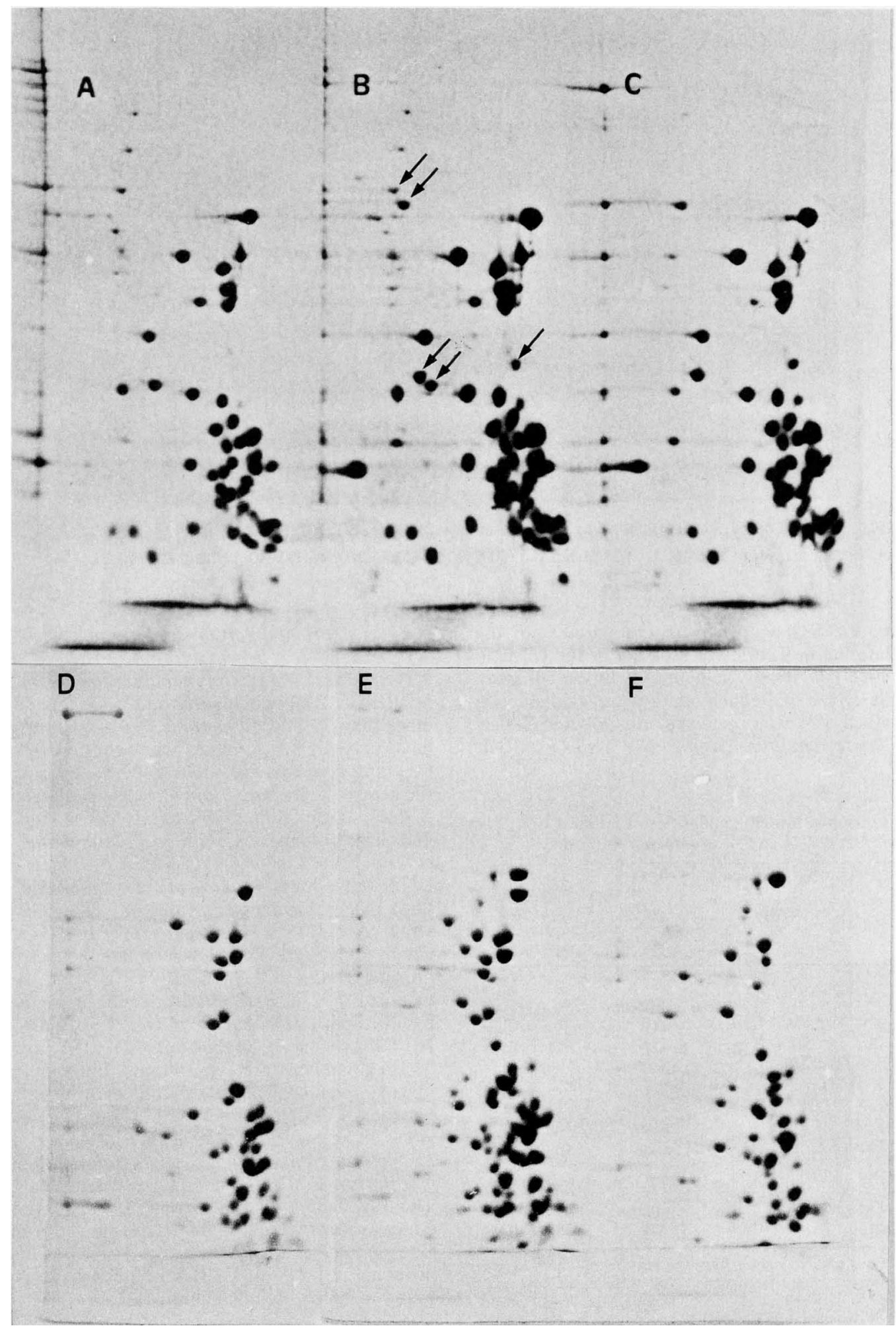

FIG. 4. Comparison of ribosomal protein spots by two-dimensional coelectrophoresis. (A) C. glutamicum KY 9002 ${ }^{\mathrm{T}}$. (B) Coelectrophoresis of $C$. glutamicum $\mathrm{KY} 9002^{\mathrm{T}}$ and "Brevibacterium lactofermentum" $\mathrm{KY} 10123$. (C) "Brevibacterium lactofermentum" KY 10123. (D) E. coli KY 3590. (E) Coelectrophoresis of E. coli KY 3590 and A. globiformis KY $3156^{T}$. (F) A. globiformis KY $3156^{\mathrm{T}}$. 


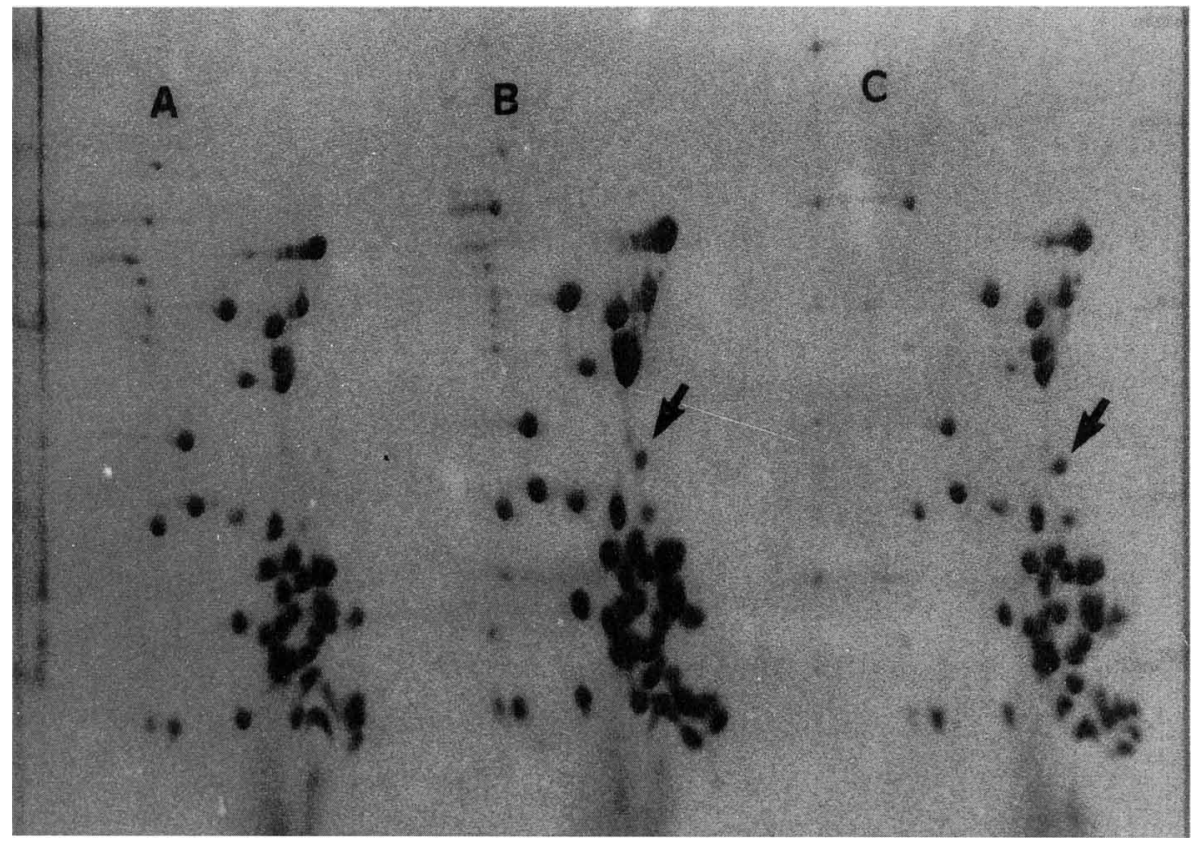

FIG. 5. Two-dimensional coelectrophoresis of mutant KY 10231 and wild-type strain KY $9002^{\mathrm{T}}$ of $C$. glutamicum. The arrows indicate the spot which was observed in mutant KY 10231. (A) Strain KY 9002 ${ }^{\mathrm{T}}$. (B) Coelectrophoresis. (C) Strain KY 10231.

ness. Therefore, the $S_{\mathrm{AB}}$ values were compared with the levels DNA relatedness. Ten species of the genus Corynebacterium and nine species of the genus Arthrobacter were selected because DNA relatedness data were available (8, 16). The $S_{\mathrm{AB}}$ values of these organisms are shown in Tables 3 and 4. "Brevibacterium divaricatum" KY 3461 (= NRRL

TABLE 2. Ribosomal protein similarities of mutants of $C$. glutamicum KY $9002^{\mathrm{T}}$ and $A$. ureafaciens $\mathrm{KY} 3152^{\mathrm{T}}$

\begin{tabular}{|c|c|c|c|c|}
\hline \multirow{2}{*}{ Strain } & \multirow{2}{*}{ Phenotype $^{a}$} & \multirow{2}{*}{ Product $^{a}$} & \multicolumn{2}{|c|}{$\begin{array}{l}\text { Ribosomal } \\
\text { proteins }\end{array}$} \\
\hline & & & $\begin{array}{l}\text { Total } \\
\text { no. }\end{array}$ & $S_{\mathrm{AB}}^{b}$ \\
\hline \multicolumn{5}{|l|}{ C. glutamicum } \\
\hline $\mathrm{KY} 9002^{\mathrm{T}}$ & & & 46 & 1.00 \\
\hline KY 10535 & Phe Tyr 5MT' $\mathrm{TrpHx}^{\mathrm{r}}$ & Trp & 46 & 0.99 \\
\hline KY 10865 & $\begin{array}{l}\text { Phe Tyr 5MT TrpHx } \\
\text { 6FT 4MT }{ }^{\mathrm{r}} \text { PFP }^{\mathrm{r}} \\
\text { TyrHx }^{\mathrm{r}} \mathrm{PheHx}^{\mathrm{r}} \text { Rif }^{\mathrm{r}} \\
\text { AS }^{\mathrm{r}} \mathrm{DR}^{\mathrm{r}} \mathrm{DON}^{\mathrm{r}}\end{array}$ & Trp & 46 & 0.96 \\
\hline KY 10694 & PFP $^{r}$ MFP $^{r}$ & Phe & 46 & 0.95 \\
\hline KY 10231 & Hom Leu PC $^{r}$ AEC $^{r}$ & Lys & 46 & 0.96 \\
\hline \multicolumn{5}{|l|}{ A. ureafaciens } \\
\hline $\mathrm{KY} 3152^{\mathrm{T}}$ & & & 46 & 1.00 \\
\hline KY 6722 & Lys & LL-DAP & 47 & 0.99 \\
\hline KY 6725 & Met & Ala & 48 & 0.98 \\
\hline
\end{tabular}

${ }^{a}$ Abbreviations: Phe, phenylalanine; Tyr, tyrosine; Hom, homoserine; Leu, leucine; Lys, lysine; Met, methionine; Ala, alanine; LL-DAP, LLdiaminopimelic acid; $5 \mathrm{MT}^{\mathrm{r}}$, resistant to 5-methyltryptophan; $\operatorname{TrpHx}^{\mathrm{r}}$, resistant to tryptophan hydroxamate; $6 \mathrm{FT}^{\mathrm{r}}$, resistant to 6-fluorotryptophan; $4 \mathrm{MT}^{\mathrm{r}}$ resistant to 4-methyltryptophan; PFPr $^{\text {r }}$, resistant to para-fluorophenylalanine; TyrHx ${ }^{r}$, resistant to tyrosine hydroxamate; $\mathrm{PheHx^{r }}$, resistant to phenylalanine hydroxamate; $\mathrm{Rif}^{\mathrm{r}}$, resistant to rifampin; $\mathrm{As}^{\mathrm{r}}$, resistant to azaserine; $\mathrm{DR}^{\mathrm{r}}$, resistant to 2-deoxyribose; $\mathrm{DON}^{\mathrm{r}}$, resistant to 6-diazo-5-oxo-L-norleucine MFPr, resistant to meta-fluorophenylalanine; $\mathrm{Pc}^{\mathrm{r}}$, resistant to penicillin; $\mathrm{AEC}^{\mathrm{r}}$, resistant to aminoethylcysteine.

${ }^{b} S_{\mathrm{AB}}$ was calculated as described in the text.
B-2311), "Brevibacterium lactofermentum" KY 10123 (= ATCC 13869), "Brevibacterium roseum" KY 10124 (= ATCC 13825), and "Corynebacterium lilium" KY 3509 (= NRRL B-2243), which exhibited DNA relatedness values of more than $70 \%$ to C. glutamicum KY $9002^{\mathrm{T}}$, were found to have very high $S_{\mathrm{AB}}$ values when they were compared with C. glutamicum (range, 0.96 to 0.98 ). Five other species of the genus Corynebacterium gave low $S_{\mathrm{AB}}$ values (range, 0.15 to 0.27 ) and exhibited DNA relatedness values of less than $24 \%$ in comparisons with C. glutamicum. Arthrobacter citreus KY 3170 (= ATCC 15170), which exhibited 73\% DNA relatedness to Arthrobacter sulfureus KY $3218^{\mathbf{T}}$ (= IAM $1488^{\mathrm{T}}$ ), gave an $S_{\mathrm{AB}}$ value of 0.89 in a comparison with strain KY $3218^{\mathrm{T}}$. A. citreus KY 3171 (= ATCC 17775), which exhibited $72 \%$ DNA relatedness to Arthrobacter protophormiae KY $3475^{\mathrm{T}}$ (= CCEB $282^{\mathrm{T}}$ ), gave an $S_{\mathrm{AB}}$ value of 0.92 in a comparison with strain $\mathrm{KY} 3475^{\mathrm{T}}$. The results with Arthrobacter polychromogenes KY $3214^{\mathrm{T}}$ (= JCM $2523^{\mathrm{T}}$ ) and $A$. globiformis KY $3156^{\mathrm{T}}$ are worth noting. These organisms are type strains, but they gave relatively high $S_{\mathrm{AB}}$ values (Table 4) in comparisons with Arthrobacter oxydans KY $3169^{\mathrm{T}}$ (= ATCC $14358^{\mathrm{T}}$ ). The DNA relatedness value for $A$. polychromogenes KY $3214^{\mathrm{T}}$ and $A$. oxydans $\mathrm{KY}$ $3169^{\mathrm{T}}$ was $61 \%$, and the DNA relatedness value for $A$. globiformis KY $3156^{\mathrm{T}}$ and $A$. oxydans KY $3169^{\mathrm{T}}$ was $43 \%$. The $S_{\mathrm{AB}}$ values for other combinations, whose DNA relatedness values were less than $31 \%$, ranged from 0.35 to 0.48 . Consequently, as shown in Fig. 6, the results of ribosomal protein similarity and DNA relatedness experiments were found to be highly correlated.

\section{DISCUSSION}

The two-dimensional polyacrylamide gel electrophoresis method developed by Kaltschmidt and Wittmann (7) has been successfully applied to analysis of bacterial ribosomal 
TABLE 3. Correlation of DNA-DNA relatedness and ribosomal protein similarity for species of the genus Conyebacterium

\begin{tabular}{|c|c|c|c|c|}
\hline \multirow{3}{*}{ Strain } & \multicolumn{4}{|c|}{ Comparison with reference strain $\mathrm{KY} 9002^{\mathrm{T}}$} \\
\hline & \multicolumn{2}{|c|}{$\%$ of DNA relatedness } & \multicolumn{2}{|c|}{ Ribosomal proteins } \\
\hline & $\begin{array}{c}\text { Method of } \\
\text { Suzuki et al. }\end{array}$ & $\begin{array}{l}\text { Method of Komatsu } \\
\text { and Kaneko }\end{array}$ & Total no. & $S_{\mathrm{AB}}$ value \\
\hline Corynebacterium glutamicum KY $9002^{\mathrm{T}}$ & 100 & 100 & 46 & 1.00 \\
\hline "Corynebacterium lilium" KY 3509 & 99 & & 46 & 0.96 \\
\hline "Brevibacterium lactofermentum" KY 10123 & & 102.1 & 46 & 0.96 \\
\hline “Brevibacterium divaricatum" KY 3461 & & 93.4 & 46 & 0.98 \\
\hline “Brevibacterium roseum" KY 10124 & & 73.5 & 46 & 0.96 \\
\hline Corynebacterium ammoniagenes $\mathrm{KY} 3453^{\mathrm{T}}$ & 24 & & 46 & 0.20 \\
\hline Corynebacterium renale $\mathrm{KY} 3028^{\mathrm{T}}$ & 22 & & 40 & 0.21 \\
\hline Corynebacterium flavescens $\mathrm{KY} 3821^{\mathrm{T}}$ & 20 & & 43 & 0.27 \\
\hline Corynebacterium vitarumen $\mathrm{KY} 3005^{\mathrm{T}}$ & 20 & & 44 & 0.15 \\
\hline Corynebacterium xerosis KY $3029^{\mathrm{T}}$ & 15 & & 43 & 0.22 \\
\hline
\end{tabular}

a See reference 17

${ }^{b}$ See reference 8 .

proteins, especially $E$. coli ribosomal proteins. One of the methods used for more quantitative comparisons, which combines the first-dimension separation system of Mets and Bogorad (11) with the second-dimension system of Kaltschmidt and Wittmann (7), was described by Böck in 1985 (1). Böck's system includes (i) a visual comparison of protein spots, (ii) measurements of the $R_{f}$ value of each protein, (iii) monitoring of gels which are run in the same chamber assembly as that devised by Kaltschmidt and Wittmann on a light box, and (iv) electrophoresis of protein mixtures. These techniques are too complicated to allow a comparison of the similarity of spots without a special apparatus for the second dimension. Moreover, the detection of different spots by superimposing two gel patterns is influenced by changes in gel expansion and contraction. For these reasons, it was thought that routine use of the method for taxon identification would require further improvements. Therefore, we examined different previously described procedures and devised an improved system by combining nonequilibrium $\mathrm{pH}$ gradient gel electrophoresis in the first dimension in glass capillary tubes with sodium dodecyl sulfate-polyacrylamide gel electrophoresis in the second dimension, using a slab gel onto which the contents of three glass capillary tubes could be applied. Our method has the following advantages over previous procedures: (i) the first- dimension run requires only about $17 \mathrm{~min}$, compared with about $2 \mathrm{~h}$ for the procedure of Dipak et al. (2) or $7 \mathrm{~h}$ for the procedure of Böck (1), and the second-dimension run requires only about $130 \mathrm{~min}$; and (ii) the individual ribosomal proteins from two organisms can be compared on one slab gel. Thus, an $S_{\mathrm{AB}}$ value for two organisms can be obtained by coelectrophoresis. Although our method did not completely separate all of the ribosomal proteins from each other, more than 40 proteins were detected as single distinct spots, which corresponded closely with the values obtained by the methods of Kaltschmidt and Wittmann (7) and other workers.

Our improved method was used to analyze a number of gram-positive bacteria (Table 1), and our results indicated that the ribosomal protein patterns were specific for each taxon. Organisms have been classified into taxonomic groups (taxa) on the basis of similarities or genetic relationships; these two approaches are phenetic classification (aiming at similarity) and phylogenetic classification (aiming at genuine relatedness). Recently, the Ad Hoc Committee on Reconciliation of Approaches to Bacterial Systematics reported that phylogeny based on the complete DNA sequence should determine taxonomy (18). This committee also proposed a recommended phylogenetic definition for a species, which is the basis of the taxonomic hierarchy, which gener-

TABLE 4. Correlation of DNA-DNA relatedness and ribosomal protein similarity among species of the genus Arthrobacter

\begin{tabular}{|c|c|c|c|c|c|c|c|c|c|}
\hline \multirow[b]{2}{*}{ Strain } & \multirow[b]{2}{*}{$\begin{array}{c}\text { Total no. of } \\
\text { ribosomal } \\
\text { proteins }\end{array}$} & \multicolumn{2}{|c|}{ Strain KY $3281^{T}$} & \multicolumn{2}{|c|}{ Strain KY $3475^{\mathrm{T}}$} & \multicolumn{2}{|c|}{ Strain KY $3169^{\mathrm{T}}$} & \multicolumn{2}{|c|}{ Strain KY $3155^{\mathrm{T}}$} \\
\hline & & $\begin{array}{c}\% \text { of DNA } \\
\text { related- } \\
\text { ness }^{a}\end{array}$ & $\begin{array}{l}\text { Ribosomal } \\
\text { protein } S_{\mathrm{AB}} \\
\text { value }\end{array}$ & $\begin{array}{c}\% \text { of DNA } \\
\text { related- } \\
\text { ness }^{a}\end{array}$ & $\begin{array}{l}\text { Ribosomal } \\
\text { protein } S_{\text {AB }} \\
\text { value }\end{array}$ & $\begin{array}{c}\% \text { of DNA } \\
\text { related- } \\
\text { ness }{ }^{a}\end{array}$ & $\begin{array}{l}\text { Ribosomal } \\
\text { protein } S_{\mathrm{AB}} \\
\text { value }\end{array}$ & $\begin{array}{c}\% \text { of DNA } \\
\text { related- } \\
\text { ness }\end{array}$ & $\begin{array}{c}\text { Ribosomal } \\
\text { protein } S_{\mathrm{AB}} \\
\text { value }\end{array}$ \\
\hline Arthrobacter sulfureus KY $3218^{\mathrm{T}}$ & 46 & 100 & 1.00 & & & & & 12 & 0.42 \\
\hline Arthrobacter citreus KY 3170 & 44 & 73 & 0.89 & & & & & 10 & 0.42 \\
\hline Arthrobacter protophormiae KY $3475^{\mathrm{T}}$ & 44 & & & 100 & 1.00 & & & 16 & 0.48 \\
\hline Arthrobacter citreus KY 3171 & 42 & & & 72 & 0.93 & & & 16 & 0.48 \\
\hline Arthrobacter oxydans KY $3169^{\mathrm{T}}$ & 43 & & & & & 100 & 1.00 & 20 & 0.43 \\
\hline Arthrobacter polychromogenes KY $3214^{\mathrm{T}}$ & 42 & & & & & 61 & 0.89 & 23 & 0.43 \\
\hline Arthrobacter citreus $\mathrm{KY} 3155^{\mathrm{T}}$ & 46 & & & & & 17 & 0.43 & 100 & 1.00 \\
\hline Arthrobacter ureafaciens KY $3152^{\mathrm{T}}$ & 46 & & & & & 31 & 0.45 & 16 & 0.39 \\
\hline Arthrobacter globiformis KY $3156^{\mathrm{T}}$ & 46 & & & & & 43 & 0.72 & 23 & 0.48 \\
\hline Arthrobacter atrocyaneus KY $3209^{\mathrm{T}}$ & 42 & & & & & 16 & 0.35 & 16 & 0.45 \\
\hline Arthrobacter nicotianae KY $3213^{\mathrm{T}}$ & 41 & & & & & 15 & 0.41 & & \\
\hline
\end{tabular}

a See reference 16 . 


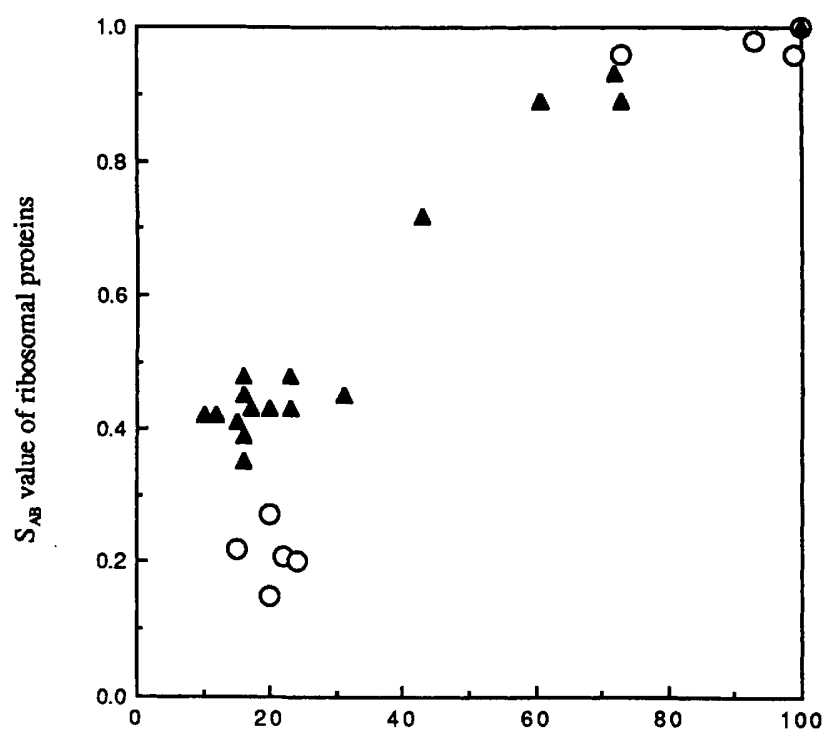

DNA-DNA Hybridization (\%)

FIG. 6. Relationship between ribosomal protein similarity and DNA-DNA relatedness. Symbols: $\boldsymbol{\Delta}$, Arthrobacter strains; 0 , Corynebacterium strains.

ally includes strains that exhibit approximately $70 \%$ or greater DNA-DNA relatedness and differences between the melting temperatures of homologous hybrids and the melting temperatures of heterologous hybrids of $5^{\circ} \mathrm{C}$ or less. In our study, ribosomal protein similarity and DNA-DNA relatedness were compared. Strains belonging to the genera Corynebacterium and Arthrobacter were found to have high correlations between the two indices. It is quite obvious that ribosomal proteins have been conserved within species during evolution. In contrast to DNA-DNA hybridization, two-dimensional analysis of ribosomal proteins can reveal differences among strains of the same species. Our improved method is a potential tool for strain identification.

Recently, "Brevibacterium divaricatum," "Brevibacterium lactofermentum," "Brevibacterium roseum," and " $C$. lilium" were proposed as synonyms of $C$. glutamicum on the basis of the results of a restriction fragment length polymorphism analysis of ribosomal DNA, as well as DNA-DNA hybridization, chemotaxonomic, and biochemical studies (10). These organisms were found to have $S_{\mathrm{AB}}$ values in comparisons with ribosomal proteins of $C$. glutamicum (range, 0.96 to 0.98 ). Hence, our results support the proposal by Lieble et al. (10). It has been suggested that $A$. polychromogenes KY $3214^{\mathrm{T}}$ is a subspecies of $A$. oxydans on the basis of the high level of DNA-DNA relatedness exhibited by these organisms (16). In our study, the $S_{\mathrm{AB}}$ value for the $A$. polychromogenes KY $3214^{\mathrm{T}}$ and $A$. oxydans ribosomal proteins was 0.89 ; this value indicated that these organisms were closely related taxonomically. A. globiformis KY $3156^{\mathrm{T}}$ is known to exhibit a DNA relatedness value of $43 \%$ in comparisons with $A$. oxydans KY $3169^{\mathrm{T}}$ (16). The $S_{\mathrm{AB}}$ value of the ribosomal proteins of these strains was 0.72 , which was significantly higher than the $S_{\mathrm{AB}}$ value for any other different Arthrobacter species (range, 0.35 to 0.48 ). As a result, the taxonomic relationship between $A$. globiformis and $A$. oxydans based on ribosomal protein comparisons has not been resolved.

\section{REFERENCES}

1. Böck, A. 1985. Analysis of ribosomal proteins by two-dimensional gel electrophoresis. Methods Microbiol. 18:109-122.

2. Dipak, B. D., L. Changchien, C. R. Nierras, W. A. Strycharz, and G. R. Craven. 1988. Identification of Escherichia coli ribosomal proteins by an alternative two-dimensional electrophoresis system. Anal. Biochem. 173:241-245.

3. Geisser, M., G. W. Tischendorf, and G. Stoffier. 1973. Comparative immunological and electrophoretic studies on ribosomal proteins of Bacillaceae. Mol. Gen. Genet. 127:129-145.

4. Geisser, M., G. W. Tischendorf, G. Stoffler, and H. G. Wittmann. 1973. Immunological electrophoretical comparison of ribosomal proteins from eight species belonging to Enterobacteriaceae. Mol. Gen. Genet. 127:111-128.

5. Geyl, D., A. Bock, and K. Isono. 1981. An improved method for two-dimensional gel electrophoresis: analysis of mutationally altered ribosomal proteins of Escherichia coli. Mol. Gen. Genet. 181:309-312.

6. Hardy, S. J. S., C. G. Kurland, P. Voynow, and G. Mora. 1969. The ribosomal proteins of Escherichia coli. I. Purification of the 30S ribosomal proteins. Biochemistry 8:2897-2905.

7. Kaltschmidt, E., and H. G. Wittmann. 1970. Ribosomal proteins. Two-dimensional polyacrylamide gel electrophoresis for finger-printing of ribosomal proteins. Anal. Biochem. 36:401412 .

8. Komatsu, Y., and T. Kaneko. 1980. Deoxyribonucleic acid relatedness between some glutamic acid-producing bacteria. Rep. Ferment. Res. Inst. (Chiba) 55:1-5.

9. Kurland, C. G. 1966. The requirements for specific sRNA binding by ribosomes. J. Mol. Biol. 18:90-108.

10. Lieble, W., M. Ehrmann, W. Ludwig, and K. H. Schleifer. 1991. Transfer of Brevibacterium divaricatum DSM $20297^{\mathrm{T}}$, "Brevibacterium flavum" DSM 20411, "Brevibacterium lactofermentum" DSM 20412 and DSM 1412, and Conynebacterium lilium DSM $20137^{\mathrm{T}}$ to Corynebacterium glutamicum and their distinction by rRNA gene restriction patterns. Int. J. Syst. Bacteriol. 41:255-260.

11. Mets, L. J., and L. Bogorad. 1974. Two-dimensional polyacrylamide gel electrophoresis: an improved method for ribosomal proteins. Anal. Biochem. 57:200-210.

12. Ochi, K. 1989. Heterogeneity of ribosomal proteins among Streptomyces species and its application to identification. J. Gen. Microbiol. 135:2635-2642.

13. Ochi, K. 1992. Electrophoretic heterogeneity of ribosomal protein AT-L30 among actinomycete genera. Int. J. Syst. Bacteriol. 42:144-150.

14. Ochi, K., S. Miyadoh, and T. Tamura. 1991. Polyacrylamide gel electrophoresis analysis of ribosomal protein AT-L30 as a novel approach to actinomycete taxonomy: application to the genera Actinomadura and Microtetraspora. Int. J. Syst. Bacteriol. 41:234-239.

15. O'Farrell, P. Z., H. D. Goodmann, and P. H. O. O'Farrell. 1977. High resolution two-dimensional electrophoresis of basic as well as acidic proteins. Cell 12:1133-1142.

16. Stackebrandt, E., and F. Fiedler. 1979. DNA-DNA homology studies among strains of Arthrobacter and Brevibacterium. Arch. Microbiol. 120:289-295.

17. Suzuki, K., T. Kaneko, and K. Komagata. 1981. Deoxyribonucleic acid homologies among coryneform bacteria. Int. J. Syst. Bacteriol. 31:131-138.

18. Wayne, L. G., D. J. Brenner, R. R. Colwell, P. A. D. Grimont, O. Kandler, M. I. Krichevsky, L. H. Moore, W. E. C. Moore, R. G. E. Murray, E. Stackebrandt, M. P. Starr, and H. G. Truper. 1987. Report of the Ad Hoc Committee on Reconciliation of Approaches to Bacterial Systematics. Int. J. Syst. Bacteriol. 37:463-464. 